\title{
Estimating pollutant emission from motor vehicles in the years 2000-2015
}

National annual emission from motor vehicles were estimated with the use, for the first time in Poland, of the COPERT software programme developed in support of official reporting under the EU cooperation framework. The quantification of vehicular emission covered the period 2000-2015. The results were analysed for the following cumulated vehicle categories: passenger cars, light commercial vehicles, heavy duty vehicles, urban buses, coaches, motorcycles and mopeds. The national annual emission from motor vehicles in Poland was found to be markedly declining. The relative national annual emission of individual pollutants was balanced against the situation in the year 2000. Starting from 2006, a distinct decreasing trend was observed for the relative national annual emission of pollutants from a representative motor vehicle; this was valid for all the substances except for nitrous oxide alone.

Key words: motor vehicles, inventory of pollutant emission, COPERT

\section{Introduction}

Estimation of pollutant emission from motor vehicles can be done only if emission modelling is used [3, 4, 6].

Quantification of pollutant emission from motor vehicles entails the use of software programmes which assist in estimating emission. The software programmes are equipped with multiple tools that help to find the most appropriate factors for modelling pollutant emission from motor vehicles. The COPERT (Computer Programme for calculating Emissions from Road Traffic) is a widely preferred solution in the European Union, for inventorying pollutant emission from motor vehicles [7-9, 11]. The COPERT model was developed under the auspices of the European Environment Agency (EEA) for compiling national reports on GHG's and other pollutant emission from road transport due to the EU Member State reporting obligations. This paper presents the results of quantifying national emission of pollutants from motor vehicles with the use, for the first time in Poland, of the COPERT 4 programme dedicated to official reporting under the EU's cooperation $[8,11]$. The estimation of pollutant emission from motor vehicles covers the years 2000-2015.

\section{The COPERT Programme}

The assumption underlying the COPERT model, likewise all models for estimating total emission of pollutants from motor vehicles, is that the total fuel consumption and the total energy consumption, as well as the total pollutant emission resulting from the use of motor vehicles with internal combustion engine, are sums of fuel consumption, energy consumption and pollutant emission, for the following states $[3,4,6-10]$ :

- internal combustion engine heated up to a stable temperature,

- heating of internal combustion engine,

- fuel evaporation from the vehicle fuel system.

The COPERT 4 programme considers elementary categories of motor vehicles taking account of their $[1,3,4$, 6-10]:

- duty,

- conventional size,
- technical specification including, among others, the combustion system, cycle, fuel type as well as car technological level regarding pollutant emission.

The following categories of motor vehicles aggregated relative to their duties (including their original English names used by the COPERT programme, and abbreviations used in this publication) $[1,3,7-9,11]$ were considered:

1. Passenger cars - PC:

- Gasoline passenger cars with spark ignition engine PC-SI-G,

- Liquefied petroleum gas passenger cars with spark ignition engine - PC-SI-LPG,

- Passenger cars with compression ignition engine PC-CI.

2. Light commercial vehicles (Light duty vehicles) - LCV:

- Light commercial vehicles with spark ignition engine - LCV-SI,

- Light commercial vehicles with compression ignition engine - LCV-CI.

3. Heavy duty trucks - HDT:

- Heavy duty trucks - rigid (heavy duty container trucks) - HDT-R,

- Heavy duty trucks - articulated (tractor units, ballast tractors) - HDT-A.

4. Urban buses - UB.

5. Coaches $-\mathrm{C}$.

6. Motorcycles - Mc.

7. Mopeds - Mp.

Basic substances, for which emission can be quantified using models of pollutant emission include [1, 3, 7-9, 11]:

- carbon monoxide - $\mathrm{CO}$,

- volatile organic compounds - VOC,

- non-methane volatile organic compounds - NMVOC,

- methane $-\mathrm{CH}_{4}$,

- groups of organic compounds including, among others: alkanes, alkenes, alkines, furans, aldehydes, ketons, cycloalkanes, aromas, polycyclic aromatic hydrocarbons - PAHs.

- nitrogen oxides $-\mathrm{NO}_{\mathrm{x}}$,

- nitric oxide - NO,

- nitric dioxide $-\mathrm{NO}_{2}$, 
- nitrous oxide $-\mathrm{N}_{2} \mathrm{O}$,

- ammonia - $\mathrm{NH}_{3}$,

- particulate matter PM from the exhaust system of an internal combustion engine,

- particulate matter PM10 from tribological elements of a vehicle,

_ particulate matter PM2.5 from tribological elements of a vehicle,

- black carbon - BC,

- carbon dioxide $-\mathrm{CO}_{2}$

- lead and its compounds reduced to lead $-\mathrm{Pb}$,

- sulphur oxides reduced to sulphur dioxide $-\mathrm{SO}_{2}$,

- heavy metals: $\mathrm{Cd}, \mathrm{Cr}, \mathrm{Cu}, \mathrm{Ni}, \mathrm{Se}$ and $\mathrm{Zn}$.

The most important input values in the COPERT programme cover $[1,3,7-9,11]$ :

- number of vehicles by elementary categories (vehicle type),

- vehicle use intensity by vehicle type - annual mileage,

- share of mileage by vehicle type and traffic conditions: in towns, outside towns, on highways and expressways in the total mileage,

- average vehicle velocity by vehicle type, under respective traffic conditions: in towns, outside towns, on motorways and on expressways,

- monthly temperature: minimum and maximum values in respective months,

- fuel sulphur content,

- fuel lead content,

- fuel element composition,

- fuel heavy metal content,

- fuel saturated vapour pressure,

- average after-start mileage by vehicle type,

Number of vehicles per cumulated category was estimated based on data contained in Poland in the Information System of the Central Register of Vehicles and Drivers (CEPiK) - Fig. 1.

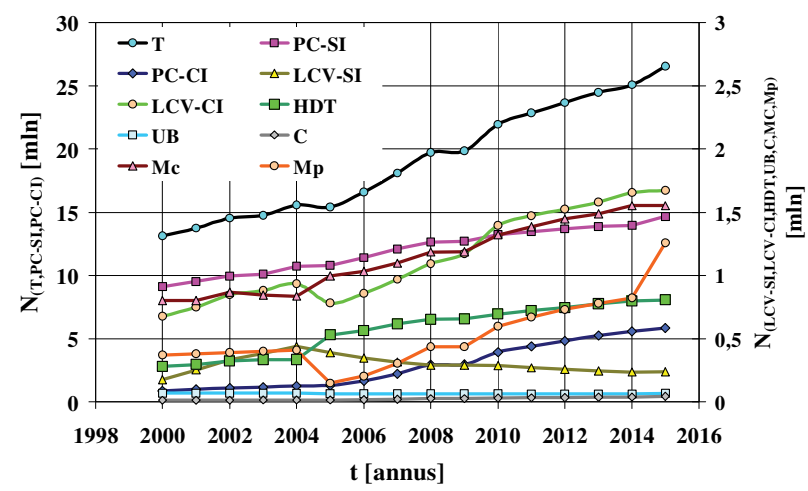

Fig. 1. Number of vehicles per cumulated category

The average mileage of vehicles by cumulated category was assessed taking into account [5]:

- transport performance,

- number of vehicles registered,

- average values of technical-operational characteristics of the road transport performance (e.g. average number of persons transported in a vehicle, average indicator of fleet utilisation, etc.).
Figure 2 illustrates the assumed annual mileage of vehicles by cumulated category.

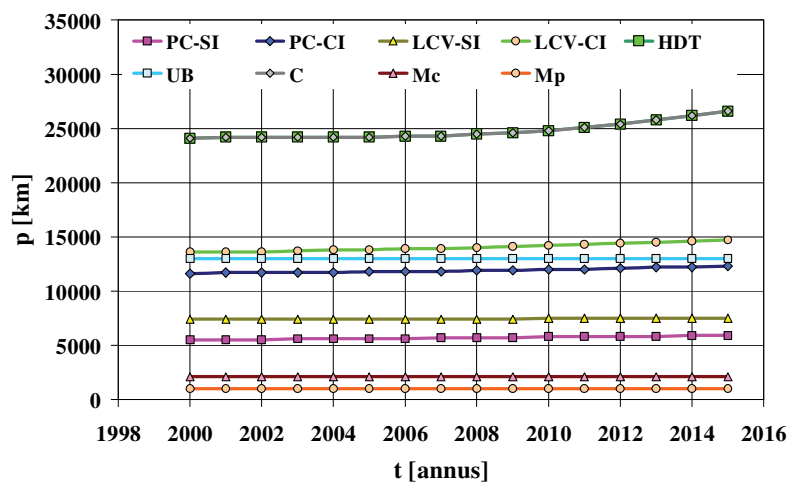

Fig. 2. Annual mileage of vehicles per cumulated category

To determine the annual mileage of motor vehicles per elementary, environmentally oriented, categories, which account for pollutant emission, the authors developed a model simulating vehicle use intensity. The model was built on the basis of functional likeness. Data on vehicle structure at the level of elementary categories were used to develop the model (data from the INFRAS software[10]).

Figures 3-5 show the assumed mileages covered by vehicles which enter the cumulated categories, under the following model traffic situations: urban, rural as well as on highways and expressways [5].

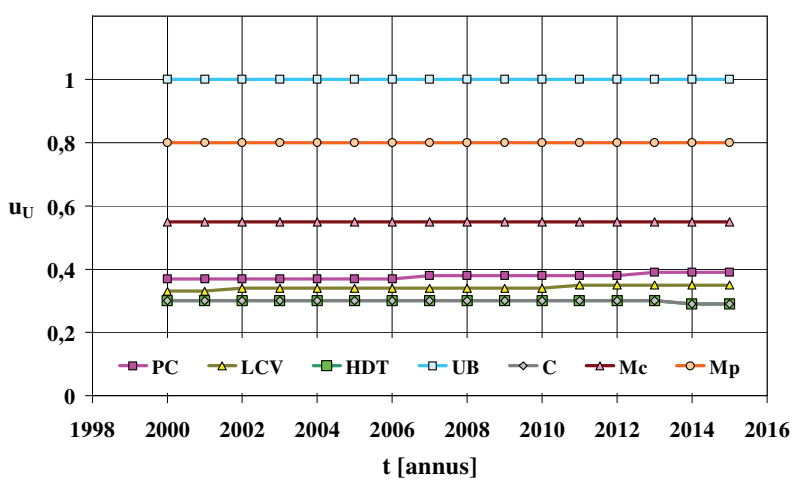

Fig. 3. Share of mileage by vehicles per cumulated category, under model traffic conditions: urban

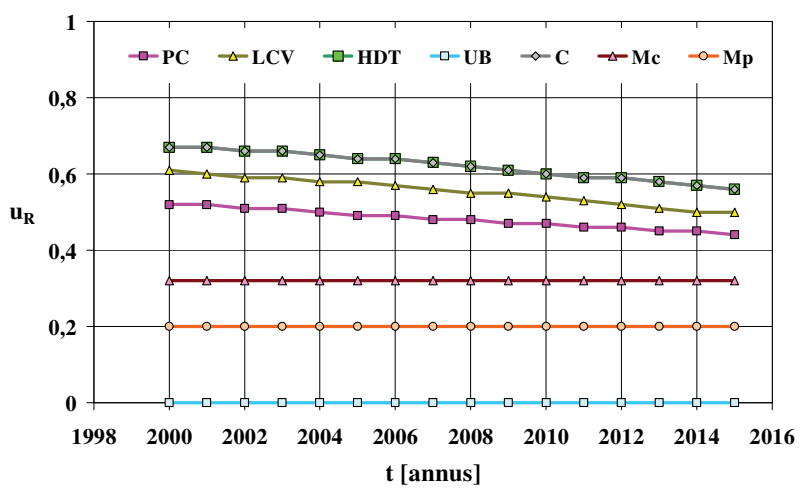

Fig. 4. Share of mileage by vehicles per cumulated category, under model traffic conditions: rural 


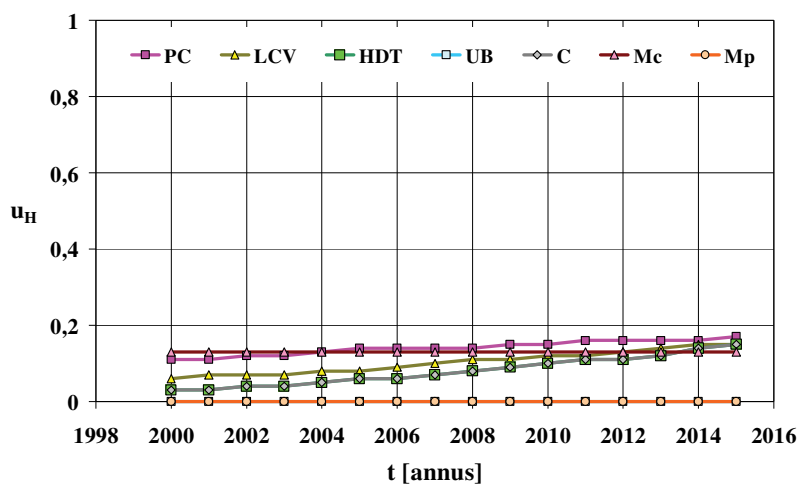

Fig. 5. Share of mileage by vehicles per cumulated category, under model traffic conditions: on highways and expressways

Figures 6-8 show the assumed average vehicle velocity per cumulated vehicle category, under the following model traffic conditions: in towns, outside towns as well as on highways and expressways [5].

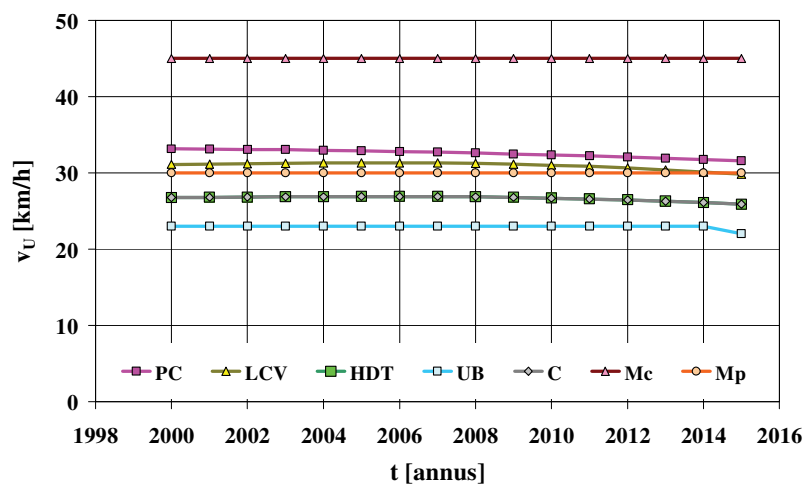

Fig. 6. Average vehicle velocity per cumulated vehicle category, under model traffic conditions: urban

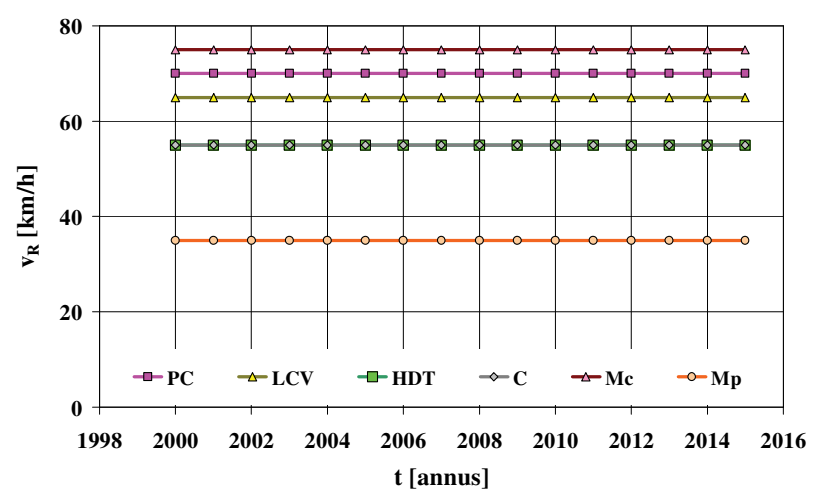

Fig. 7. Average vehicle velocity per cumulated vehicle category, under model traffic conditions: rural

The average mileage of vehicle after engine start was assumed to be $12 \mathrm{~km}$ [1].

Moreover, other data were also assumed following those addressed by the COPERT software, such as e.g.: parameters characterising fuel types and climate conditions in Poland.

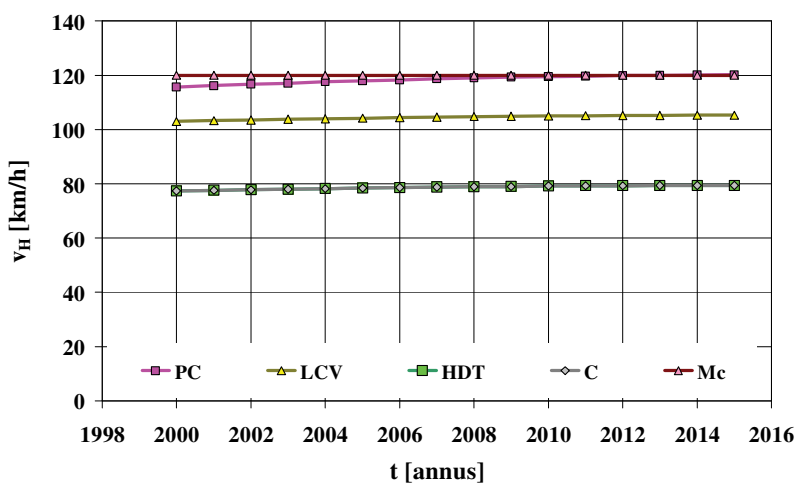

Fig. 8. Average vehicle velocity per cumulated vehicle category, under model traffic conditions: on highways and expressways

\section{Estimating pollutant emission from motor vehicles in the years 2000-2015: the results}

Figures 9-18 show the national annual emission of selected pollutants for respective cumulated categories of vehicles and for all motor vehicles $-\mathrm{T}$.

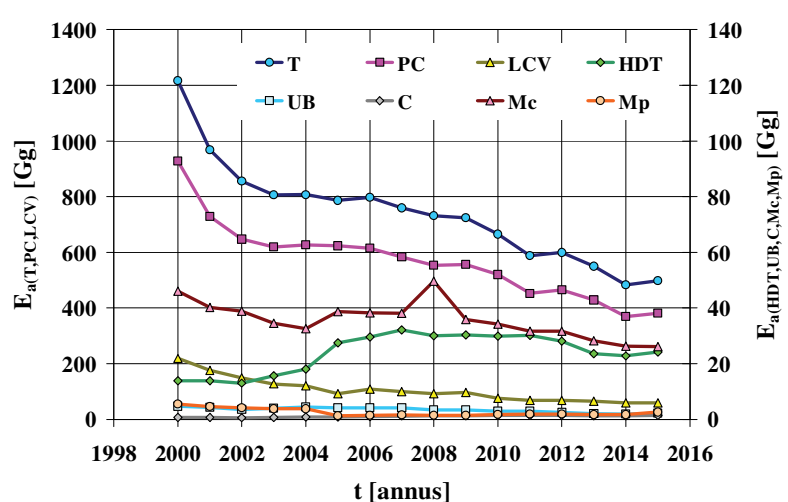

Fig. 9. National annual emission of carbon monoxide per cumulated vehicle category

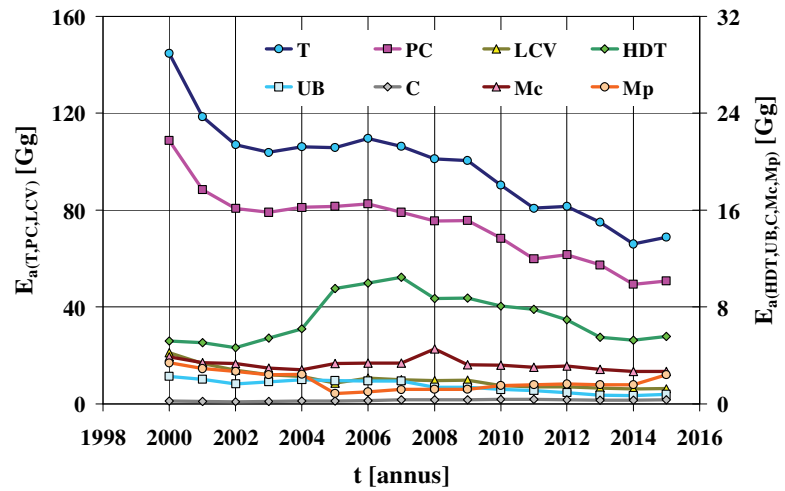

Fig. 10. National annual emission of volatile organic compounds per cumulated vehicle category

National annual emission is differentiated for different pollutants and cumulative vehicle categories. Generally for carbon monoxide and volatile organic compounds, there is a marked tendency of declining national annual emission. 


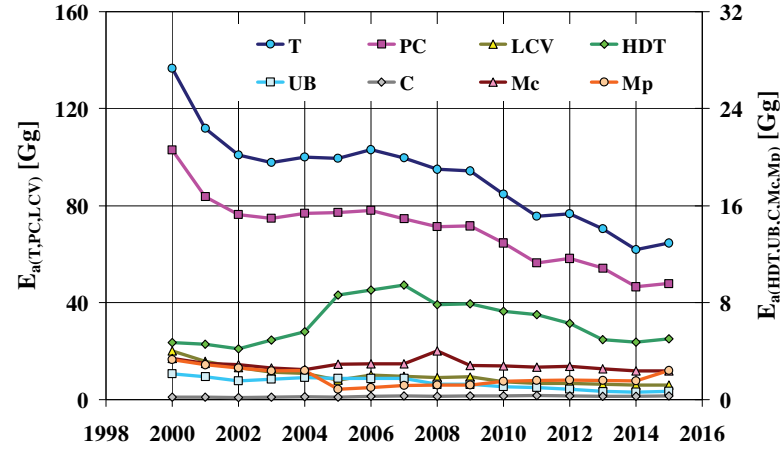

t [annus]

Fig. 11. National annual emission of non-methane volatile organic compounds per cumulated vehicle category

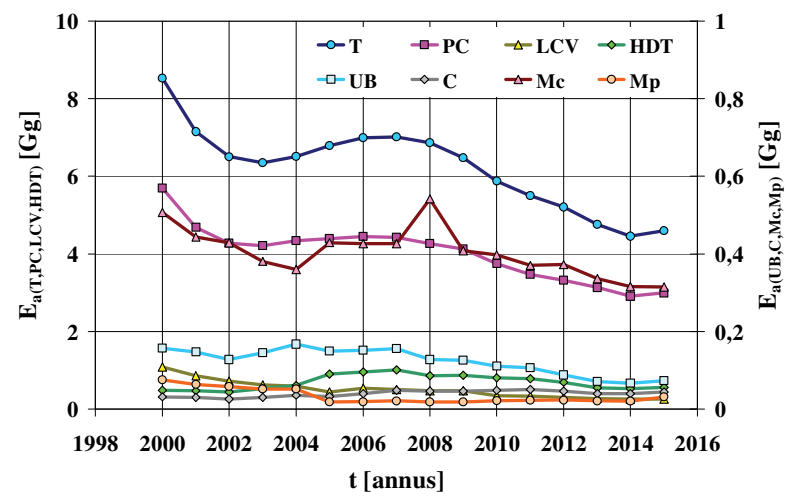

Fig. 12. National annual emission of methane per cumulated vehicle category

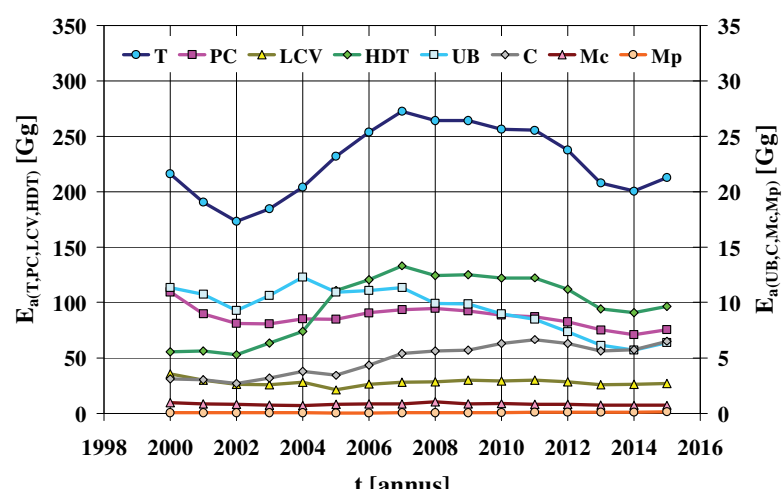

Fig. 13. National annual emission of nitrogen oxides per cumulated vehicle category

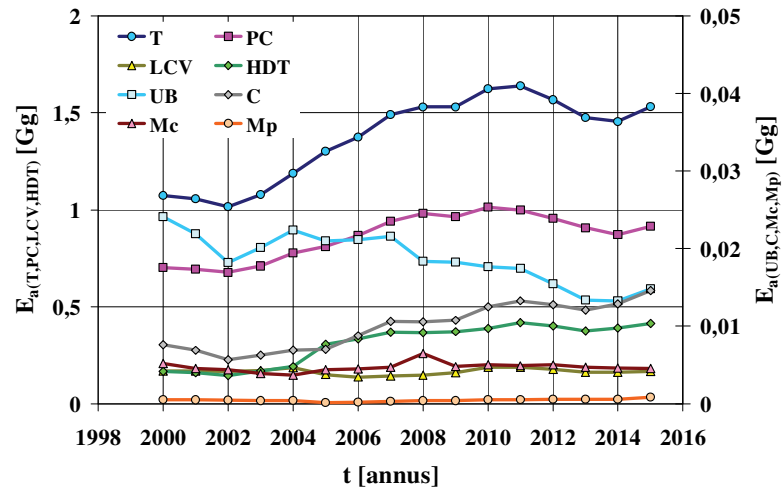

Fig. 14. National annual emission of nitrous oxide per cumulated vehicle category

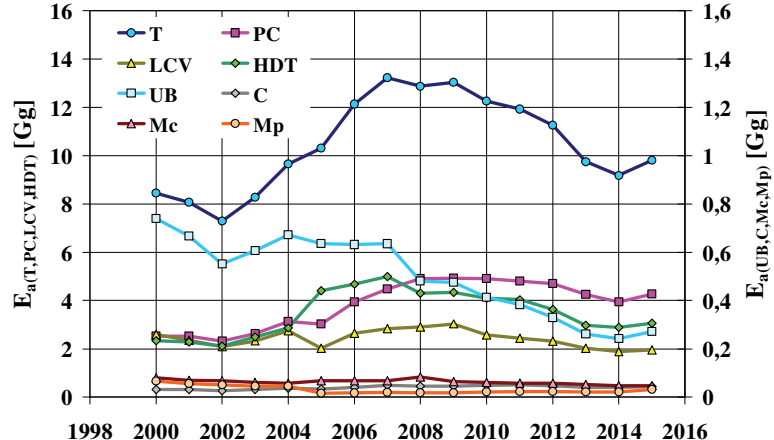

t [annus]

Fig. 15. National annual emission of particulate matter PM2.5 from tribological elements per cumulated vehicle category

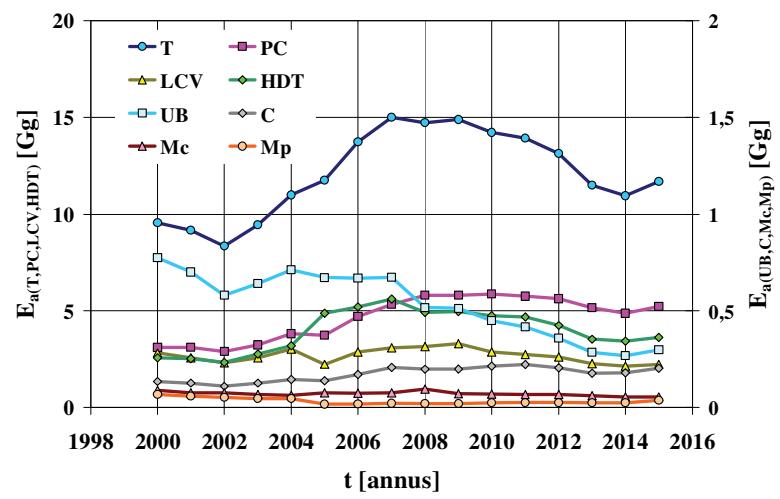

Fig. 16. National annual emission of particulate matter PM10 from tribological elements per cumulated vehicle category

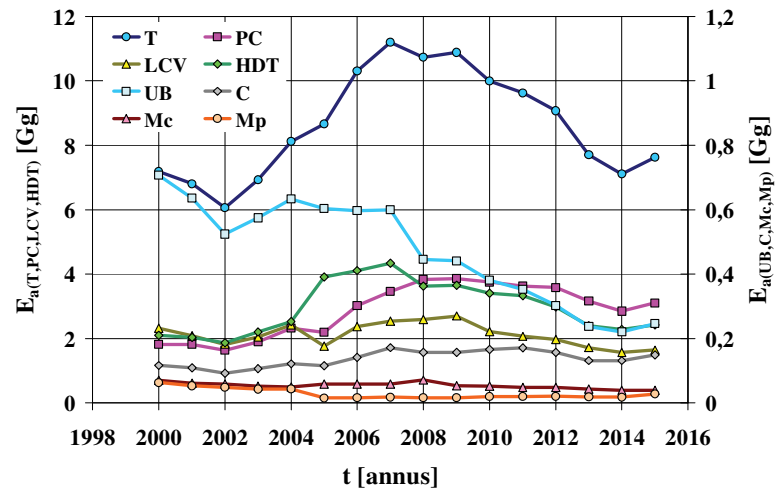

Fig. 17. National annual emission of particulate matter from the exhaust system of internal combustion engines per cumulated vehicle category

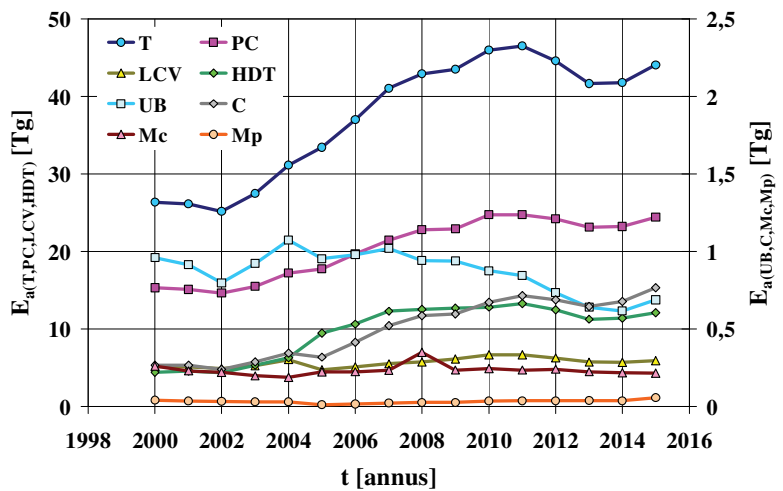

Fig. 18. National annual emission of carbon dioxide per cumulated vehicle category 
Figure 19 shows the relative national annual emission of individual pollutants from all motor vehicles, versus the national annual emission in 2000.

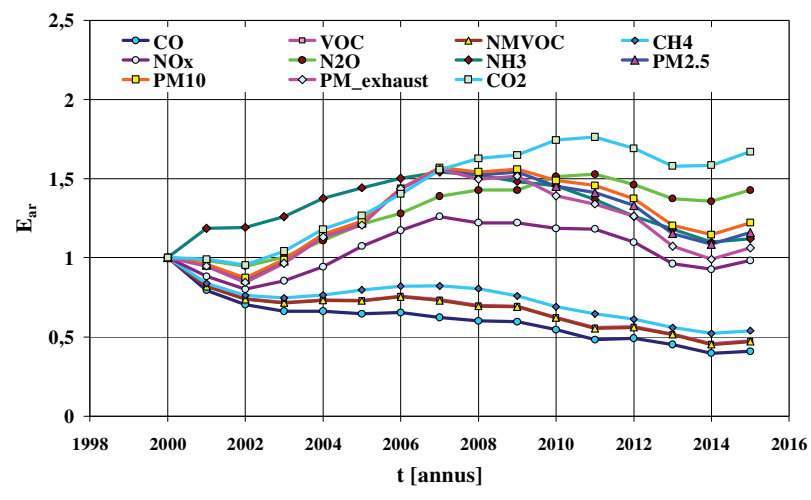

Fig. 19. Relative national annual emission of individual pollutants

In figure 20 , there is presented the relative national annual emission of individual pollutants from one conventional motor vehicle, versus the national annual emission in 2000 .

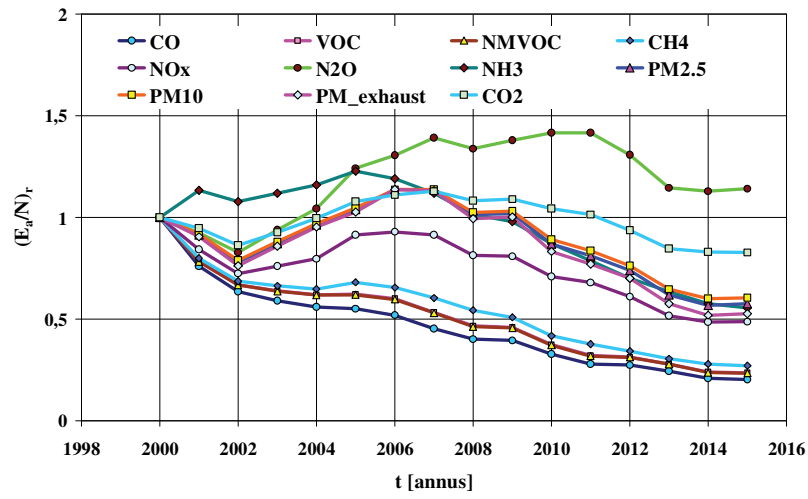

Fig. 20. Relative national annual emission of individual pollutants from one conventional motor vehicle
It is clear from Figures 19 and 20 how significant progress has been made in the field of automotive environmental protection. The greatest progress is for the emission of carbon monoxide and volatile organic compounds. It is also important to see a positive trend for carbon dioxide emissions.

\section{Conclusions}

Based on the study results presented above, the following conclusions can be drawn:

1. For the majority of harmful substances, the emission of which is limited by European regulations, there is a clear trend of decreasing national annual emission for subsequent years of inventory, although the number of vehicles and the intensity of their use have been considerably increasing. This trend is especially pronounced for carbon monoxide and volatile organic compounds. In the case of nitrogen oxides and particulate matter, the tendency for domestic annual emission to decline is from around 2007.

2. In the case of substances, the emission of which is not limited by European regulations, the increase in national annual emission is mainly attributed to nitrous oxide. In addition, the national annual carbon dioxide emission increased until 2011 and, since that time, there were minor changes. This emission is directly related to the consumption of motor fuels.

3. The relative national emission from one conventional motor vehicle shows a clear declining trend since 2006. This results from technological progress in the development of new constructions of motor vehicles.

On the basis of the experience gained with the inventory of pollutants from motor vehicles in Poland, in the years 2000-2015, the COPERT 4 software is an effective tool to support the study of pollutant emission from road transport. The most serious problem of modelling total emission from road transport is the determination of the intensity of use of motor vehicles classified to respective categories and the identification of their traffic patterns.

\section{Nomenclature}

\begin{tabular}{|c|c|c|c|}
\hline $\begin{array}{l}\mathrm{C} \\
\mathrm{CH}_{4}\end{array}$ & $\begin{array}{l}\text { coaches } \\
\text { methane }\end{array}$ & $\mathrm{p}$ & $\begin{array}{l}\text { annual mileage of vehicles per cumulated } \\
\text { category }\end{array}$ \\
\hline $\mathrm{CI}$ & compression ignition & PC-SI & passenger cars - spark ignition (engine) \\
\hline $\mathrm{CO}$ & carbon monoxide & PC-SI-G & passenger cars - spark ignition - gasoline \\
\hline $\mathrm{E}_{\mathrm{a}}$ & national annual emission & PC-SI-G & passenger cars - spark ignition - liquefied \\
\hline $\mathrm{H}$ & highway & & petroleum gas \\
\hline HDT & heavy duty trucks & $\mathrm{R}$ & rural \\
\hline HDT-A & heavy duty trucks - articulated & SI & spark ignition \\
\hline HDT-R & heavy duty trucks - rigid & $\mathrm{T}$ & total (vehicles) \\
\hline LCV & light commercial vehicles & $\mathrm{t}$ & time \\
\hline LCV-CI & $\begin{array}{l}\text { light commercial vehicles - compression ignition } \\
\text { (engine) }\end{array}$ & $\mathrm{u}$ & $\begin{array}{l}\text { share of mileage of vehicles per cumulated } \\
\text { category under model traffic conditions }\end{array}$ \\
\hline \multirow[t]{2}{*}{ LCV-SI } & light commercial vehicles - spark ignition & $\mathrm{U}$ & urban \\
\hline & (engine) & UB & urban buses \\
\hline Mc & motorcycles & $\mathrm{v}$ & average velocity of vehicles per cumulated \\
\hline $\mathrm{Mp}$ & mopeds & & category \\
\hline $\mathrm{N}$ & number of vehicles per cumulated category & VOC & volatile organic compounds \\
\hline
\end{tabular}


Estimating pollutant emission from motor vehicles in the years 2000-2015

$\mathrm{N} \quad$ number of motor vehicles

$\mathrm{N}_{2} \mathrm{O} \quad$ nitrous oxide

$\mathrm{NH}_{3} \quad$ ammonia

NMVOC non-methane volatile organic compounds

$\mathrm{NO}_{\mathrm{x}} \quad$ nitrogen oxides

PC passenger cars
PC-CI passenger cars - compression ignition (engine)

$\mathrm{PM}_{\text {exhaust }}$ particular matter from exhaust system

PM10 particular matter PM10 from tribological elements of a vehicle

PM2.5 particular matter PM2.5 from tribological elements of a vehicle

\section{Bibliography}

[1] BEBKIEWICZ, K., CHŁOPEK, Z., SZCZEPAŃSKI, K., ZIMAKOWSKA-LASKOWSKA, M. Results of air emission inventory from road transport in Poland in 2014. Proceedings of the Institute of Vehicles. 2017, 1(110), 7788.

[2] BEBKIEWICZ, K., CHŁOPEK, Z., SZCZEPAŃSKI, K., ZIMAKOWSKA-LASKOWSKA, M. The influence of the properties of vehicles traffic on the total pollutant emission. Proceedings of the Institute of Vehicles. 2017, 1(110), 89102

[3] BEBKIEWICZ, K., CHŁOPEK, Z., SZCZEPAŃSKI, K. ZIMAKOWSKA-LASKOWSKA, M. Issues of modeling the total pollutant emission from vehicles. Proceedings of the Institute of Vehicles. 2017, 1(110), 103-118.

[4] BUWAL (Bundesamt für Umwelt, Wald und Landschaft), INFRAS AG (Infrastruktur-, Umwelt- und Wirtschaftsberatung). Luftschadstoffemissionen des Strassenverkehrs 19502010. BUWAL-Bericht Nr. 255, 1995.

[5] CHŁOPEK, Z., WAŚKIEWICZ, J. The forecast of the pollutant emission from automotive internal combustion

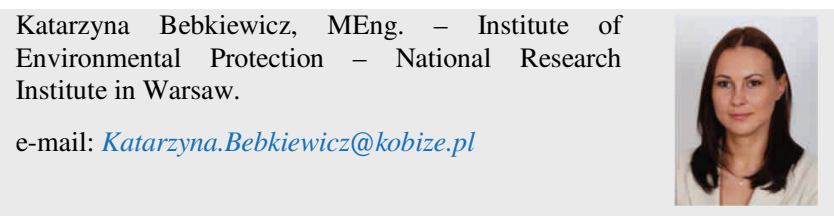

Prof. Zdzisław Chłopek, DSc., DEng. - Institute of Environmental Protection - National Research Institute in Warsaw.

e-mail: Zdzislaw.Chlopek@kobize.pl engines in Poland by 2030. VI International Congress of Internal Engines. Combustion Engines 2015.

[6] CHŁOPEK, Z. Zasady modelowania zużycia paliwa i energii oraz emisji zanieczyszczeń związanych $\mathrm{Z}$ użytkowaniem pojazdów drogowych. Technika Transportu Szynowego. 2015, 12, 262-267.

[7] COPERT Training 5. COPERT 5 vs COPERT 4. European Environment Agency. 2016. emisia.com/sites/default/ files/COPERT_5_features.pdf (accessed 2016.12.06).

[8] EMEP/EEA air pollutant emission inventory guidebook 2016. European Environment Agency. www.eea.europa. eu/publications/emep-eea-guidebook-2016 (accessed 2016. 12.06).

[9] GKATZOFLIAS, D., KOURIDIS, CH., NTZIACHRISTOS, L., SAMARAS, Z. COPERT 4 Computer programme to calculate emissons from road transport User manual (version 9.0). European Environment Agency. Emisia SA. 2012. (accessed 2016.12.06).

[10] INFRAS AG. Handbook emission factors for road transport 3.2. Quick reference. Version 3.2. Bern, 2014.

[11] 2006 IPCC Guidelines for National Greenhouse Gas Inventories. www.ipcc-nggip.iges.or.jp/public/2006gl /vol2.html. (accessed 2016.12.06).

Krystian Szczepański, DSc., DEng. - Institute of Environmental Protection - National Research Institute in Warsaw.

e-mail: Krystian.Szczepanski@ios.edu.pl

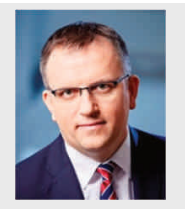

Magdalena Zimakowska-Laskowska, DSc., DEng. Institute of Environmental Protection - National Research Institute in Warsaw.

e-mail:Magdalena.Zimakowska-Laskowska@kobize.pl 